ventricular ejection time 等を検討した。本法は非観血 的に短時間で左心機能を評価できることから臨床上有用 な方法と思われた。

214. $133 \mathrm{Xe}$ 冠動脈内投与による心筋属所血流の測定 (滋賀成人病センター循環器内科) 田巻 俊一 本原征一郎・上鼻拓・尾藤 縻三 玉井 落男・芹生 陽一

（同 循環器外科）安田隆三郎・平田 和男 (京大 放射線核医学科) 米食 義晴 向井孝夫・石井靖 $\cdot$ 鳥塚 莞爾

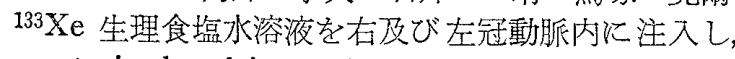
computerized multicrystal gamma camera (System 77) を用いその洗い出し過程を記録. デーダをミニコンピュ 一タで解析して心筋局所血流量を求めた，虚血性心疾患， 肥大型心管症を対象とし， ${ }^{201} \mathrm{Tl}$ 心筋シンチグラム，冠

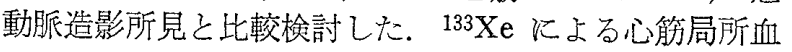
流量の湘定は，心筋重量の影響を受けることなく，冠末 梢血流分布を直接描出することが可能であると考党られ t.

\section{RI アンジオによる左空壁運尌の飧討}

一虚血性心疾患

(関西医大 第二内科) 瀬尾一郎・渡辺 美郎 酒井章・㙏田登志也

（间放射線科）笠原明

Computerized multi-crystal gamma camera (System 77）を用いて RI アンジオ像の左室壁動態を検討した。 対象は陳昍性心筋顺塞11例，槓塞の既往のない坟心症13 例で RI 所見と心電図との刘比を行った。駆出分劃はと れぞれ平均48\%及び72\%で有意に梗塞例で低值を示した。 壁運動は収縮及び拡張汒期辺縁重畳像之駆出分劃分布像 により評価した。梗塞群では Ecg 所見に一致した異常が ほぼ全例に認められたが，狭心症例では明確な壁運動暴 常を認めえなかった。

216. Cardiac probe system およびプール・ゲイト流 による冠状動脈䛈害の左心機能諲価

（都立養育院病院 核放部）中居 賢司 飯尾 正宏·村四啓・川口新一郎 外山比南子・千葉 一夫・山田 英夫

Cardiac probe system 学用い15症例で安静時特よび Isometric Handgrip 負荷 (H-GEx.) 時に括ける左室駆出 分画 (LVEF) を测定した。 また，心プールゲイト法では 7 症例で H-GEx. 特よび冠拡張剤投与前後での LVEF, $\mathrm{dv} / \mathrm{dt}$ ，局所左室壁の収縮栏式について检討した。両方 法による梌討により，冠状動脈疾患群の LVEF は安静 時では正常群之大至なかったが，負荷により LVEF， $\mathrm{dv} / \mathrm{dt}$ ともに低下し，局所左室壁の収縮異常も6 例中 2 例仿られた。

\section{7. 動的非観血的左心機能評価に関する䠛床的研究} （第7報）虚血性心疾患における Dynamic Systolic Time Intervals と左室造影, 冠䣦脈写及び負荷心 筋シンチグラムとの対比

（神戸大 籍一内科）石田健次部・小林 克也
韓在晢・戸田 常紀・土岐 保正 中島 義治・銕 䙾之・藤原 克昌 前田 和美・福崎 恒

虚血性心疾患 (IHD), 正裳群にて虎報の如くDynamic Systolic Time Intervals (DSTI) をマスター2 重負荷試 験前, 中, 後を通じ観察, 左空造影, 冠動脈写, 心筋シ ンチと比較検討. PEP, PEP/ET は EF と相関し， EF 低下，左室壁運動異常例飞 ETI 反応異常を多く認め, 冠血流障害強度例に心機能低下の可能性が 示唆された。 DSTIKより群間比較や IHD 各症例の左心機能判定が 可能で, 非観血的, 簡便, 反復可能等の利点を有し, 臨 休上有用であった。

\section{(16:20-17:30) 座長 飯尾 正宏(都養龍院)}

218. 慢性呼吸器矣患の右室肥大把握手段としての Thallium-201 心筋シンチグラムの意義 (羽曳野病院 内科) 川合 清毅・田中 信之 沢田 雅光・藤本 繁夫・藤田 一誠 (同 RI 科) 福永 義純・北野 保 (大阪市大 第一内科) 西本正紀・田中忠治郎 塩田慧三

慢性呼吸器疾㶳患者にタリウムー201心筋ンンチ妾施 行し肺動脈平均压との関係をるた。 シンチ上の（左室十

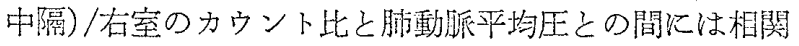
係数 $R=-0.76$ と高度の負の相関を示した。 また剖榆例 3 例についても (左室十中隔)/右室の重量比とシンチ上 のカウント比と比較的よく一致した。 以上より心筋シン チのカウント比文右室肥大や肺動脈王上犁の程度を非観 血的に把握する乎段として有用であると考觉られた。

219. タリウムー201 心筋 シンチグラフィーにおける右 心負荷の定量的評価に関する湌討

（福島医大 第一内科）大和田急司・蛕谷钯 舟山進・室井 秀一・池田 精㚐 麻喜 恒雄・待井一男・内田 立身 刈米 重夫

右心カテーテルを行った各種心疾患にタリウムー201心 筋シンチグラフィー学行い，右心負何の定量的語洒学試 みた， $2 \mathrm{mCi}$ のタリウムー201静脈内投与後，左前斜位像 にて右心自由壁 (RV) と心室中隔 (IVS) K ROI 決め,

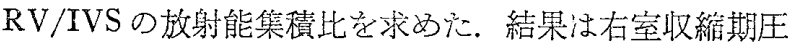
$30 \sim 40 \mathrm{mmHg}$, 肺動脈平均圧 15 20 $\mathrm{mmHg}$ 以上で右心 自由壁の描出がみられ，RV/IVS 比は右室圧と良い相䦙 を示し，非観血的な右心負荷の鿉佂として臨床的に有用 と思われた。

220. Dypiridamole 負荷 ${ }^{201} \mathrm{Tl}$ 心箁シンチグラフィー による虚血性心疾患の診断

(住友病院 内科) 成田 充㤵・槑原正 宇佐美陽久・瓦谷 仁志・吉川 敏朗

dipyridamole 負荷 ${ }^{201} \mathrm{~T} 1$ 心筋シンチグラフィ一の虚血 性心疾患診断に対劣る有効性を，冠動脈結樂犬と，臨床 例で袷討した。冠動脈結禁犬で， dipyridamole は，健 常心筋の Tl 提取㕝1.6倍とし，虚血部々 Tl の濃度の差 索明瞭と乙た。虚血性心疾患 12 例中 3 例では， dipyridamole 負荷シンチが算動負荷シンチより診断能力にお 
いて勝っていたが，逆の例も存在した. dipyridamole 負荷，運動負荷心筋シンチの併用は，虚血性心疾患の非 観血的診断に有効である.

\section{1. 虚血性心疾患の研究}

\section{一心筋シンチ数量化による判定一}

(聖マリアンナ医大 第二内科) 城間 剛 外園 光一・峯木 仁志・小池 芳樹 小泉 真・三宅 良彦・三川 武彦 山本 豊・岡村 哲夫・須階 二朗 （同 第三内科）佐々木康人・山本 光祥 （同放射線部核医学）楖 德市 冠動脈造影を施行した虚血性心疾患 20 例に ${ }^{201} \mathrm{Tl}$ 負荷 心餎シンチを行ない，心筋肺血流量比 (以下 W/L)にて 定量化し知見を得たので報告する。(結果)正常群のは安 静特に比して約 $40 \%$ の增加资示し，冠動脈狭窄があり副 血行路の発達の覀い群では，安静時に比してW/L の増 加を認めず，副血行路の発達した狭窄群では，W/L の 增加率は注济正常ですった．以上の結果より心筋シンチ 老定量化することにより虚血度合和よび治潦効果の判定 を出来ることが明らかになった。

\section{2. 心筋梗塞例の 201 T1 心筋シンチグラフィー 各種臨床的指標との対比}

（阪大 中央放射線部） 木村 和文・恵谷 秀紀

(阪大 第一内科) 石田 良雄・并上通敏 浜中 康彦・福島 正勝・堀 正二 福並 正剛・多田 道彦・松尾 裕英
阿部裕

（国立循環器病センター）西村 恒彦 （桜橋渡辺病院 循環器内科）扇谷 信久 福井須賀男・南野 隆三

心筋梗塞例の心機能・予後を決定する要因として，梗 塞量・梗塞部位の関与以大き化重を占める。本研究で は，201Tl 心筋シンチグラフィによる梗塞部位診断・梗

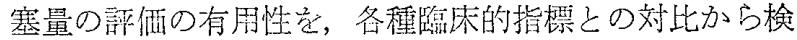
討した，心筋梖塞50例で，本法より检仙した image defectの出現部位は，LVG で認められた Asynergyの部 位とよく一致した，全心筋に対する defect 部位の面積 比で算出した\% scintigraphic infarct size は総 CPK 遊 出量・胸壁面 ST マッピングから得た こST と良い相関 をみた。（ $(\mathrm{r}=0.86, \mathrm{r}=0.82)$

223. 冠動脈側副血行路と心筋シンテグラフィー

(京大 第三内科) 神原 啓文・門田 和紀 川下 憲二・吉田章・若林章 河合 忠一

（京大 核医学科）石茾 靖・米倉 義晴 山本 和高・鳥塚 莞爾

選択的冠動脈造影で側副血行路の形成意認めた症例和 よび側副血行路未発達の 2 群について心筋シンチグラフ ィーと心電図の面より榆討した，左心室造影所見ならび に安静および負荷心電図で両群に差を認めず，また心筋 シソチグラフィーの上でも両群に差は認めなかったが， これは側副血行路が心等局所血流の維持にある程度の役 割を有することを示唆する. 